DOI: http://dx.doi.org/10.18185/eufbed.22429

EÜFBED - Fen Bilimleri Enstitüsü Dergisi Cilt-Sayı: 8-2 Yıl: 2015 201-212

\title{
EFFECT OF SOME DRUGS ON SHEEP LIVER CARBONIC ANHYDRASE I AND II
}

\section{BAZI İLAÇLARIN KOYUN KARACİĞERİ KARBONIK ANHIDRAZ I VE II ÜZERINNDEKİ ETKİSİ}

\section{Mehmet KUZUCU, Murat CANKAYA*}

${ }^{1}$ Erzincan Üniversitesi Fen Edebiyat Fakültesi Biyoloji Bölümü

\author{
Erzincan, TÜRKIYYE
}

Geliş Tarihi (Received): 30/01/2015 Kabul Tarihi (Accepted): 10/06/2015

\begin{abstract}
Effects of clindamycin, dexketoprofen trometamol, benzylpenicillin (penicillin G) and phenoxymethylpenicillin (penicillin V) were examined on purified sheep carbonic anhydrase I and II (SCAI, SCA-II). In our study, we were chosen sheep liver tissue; because the liver is responsible for detoxification of xenobiotics. The CA isozyme have a very important duties on organisms, the effect of xenobiotics on the CA enzyme was reported. It was observed these drugs exhibited the inhibition effects against liver carbonic anhydrase isozymes I and II in our study. SCA I and SCA II isozymes were purified with about a specific activity of $1108.51 \mathrm{EU} / \mathrm{mg}$ and $5706.67 \mathrm{EU} / \mathrm{mg}, 120.62$ and 620.96 purification fold by using Sepharose-4B-L tyrosine-sulfanilamide affinity gel chromatography. Purity of the SCA I and SCA II isozyme was checked by SDS-PAGE technique and subunit molecular masses of the SCA I was found as $29 \mathrm{kDa}$ and SCA II found as 31 $\mathrm{kDa}$. The usage of clindamycin, dexketoprofen trometamol, benzylpenicillin (penicillin G) and phenoxymethylpenicillin (penicillin V) in sheep liver especially during necrotic hepatitis disease is important for scientific researches. Many antibiotic and antihistamine may have dangerous effect to sheep liver. Also, it is important to study the inhibition effects of these drugs on SCA I and II isozymes.
\end{abstract}

Key words: Liver, Antibiotics, Inhibition.

ÖZET

Koyun karaciğerinden saflaştırılmış karbonik anhidraz I ve II (SCAI, SCA-II) üzerine; klindamisin, deksketoprofen trometamol, benzilpenisilin (penisilin G) ve fenoksimetilpenisilin (penisilin V)'in etkileri incelenmiştir. Çalışmamızda koyun karaciğer dokusunu seçtik, çünkü karaciğer ksenobiyotiklerin detoksifikasyonundan sorumludur. Karbonik anhidraz izoenzimlerinin organizmalarda çok önemli görevleri vardır, ksenobiyotiklerin karbonik anhidraz üzerindeki etkileri rapor edilmiştir.

*Sorumlu Yazar: mcankaya@erzincan.edu.tr 
Effect of Some Drugs on Sheep Liver Carbonik Anhydrase I and II

Çalışmamızda bu ilaçların, koyun karaciğeri karbonik anhidraz I ve II izoenzimlerine karşı inhibisyon etkisi gösterdiği gözlenmiştir. SCA I ve SCA II izoenzimleri Sepharose-4B-L tyrosine-sulfanilamid afinite jel kromatografisi kullanılarak, yaklaşık olarak $1108.51 \mathrm{EU} / \mathrm{mg}$ ve 5706.67 $\mathrm{EU} / \mathrm{mg}$ spesifik aktivite ile 120.62 ve 620.96 kat saflaştırıldı. SCA I ve SCA II izoenzimlerinin saflığı SDS-PAGE tekniği ile tespit edildi ve alt birimlerinin ağırlığı SCA I'de $29 \mathrm{kDa}$ ve SCA II'de $31 \mathrm{kDa}$ olarak belirlendi. Koyun karaciğerinde, özellikle nekrotik hepatitis hastalığı sırasında kullanılan; klindamisin, deksketoprofen trometamol, benzilpenisilin (penisilin G) ve fenoksimetilpenisilin (penisilin V) hakkında önemli araştırmalar yapılmaktadır. Birçok antibiyotik ve antihistamin koyun karaciğeri için tehlikeli etkilere sahip olabilir. Ayrıca, bu ilaçların SCA I ve II izoenzimleri üzerinde inhibisyon etkilerini incelemek oldukça önemlidir.

Anahtar Kelimeler: Karaciğer, Antibiyotik, İnhibisyon.

\section{INTRODUCTION}

The most hard-working organ of the human body is liver. Therefore function and activity of liver are vital to life. Most of investigations focus on the property of liver. This organ is a crucial organ present in vertebrates and some other animals. Functions of this organ have a wide range, such as including protein synthesis, production of biochemical necessary for detoxification and digestion. Liver plays a vital role in metabolism and has so many different functions in the body, detoxification, and decomposition of red blood cells, including plasma protein synthesis, hormone production and glycogen storage. It is the storage site for many important minerals and vitamins, such as all of fat-soluble vitamins, iron, and copper. Numerous significant metabolic processes occur in the liver such as detoxification, urea Cycle. Many different chemical reactions in the liver detoxify harmful substances. (Demirdag, 2012; Evenepoel, 2006; Kmieć, 2001).

On the other hand, enzymes are very important for the life attendance. Carbonic anhydrases is a crucial family in enzymes because they catalyze the reversible reactions of $\mathrm{CO}_{2}$ and water (Brinkman, 1932; Meldrum, 1933; Stadie, 1933).

CA isozymes are tried a lot of because the turnover number or $\mathrm{k}_{\mathrm{cat}}$ of some members of this family exceed $1 \times 10^{6} \mathrm{~s}^{-1}$ (Chegwidden, 2000). In addition, the reaction of CA isozymes are essential to several of physiological processes such as photosynthesis, calcification, respiration, acid-base and fluid balance, cell growth, ionic and

EÜFBED - Fen Bilimleri Enstitüsü Dergisi Cilt-Sayı: 8-2 Yıl:2015 201-212 
Çankaya ve Kuzucu

metabolism (Tashian, 2000). Therefore, most of the analysis exhibited expression of CA isoforms almost ubiquitously in living organisms. CAs consists of five different genetic families $(\alpha, \beta, \gamma, \delta$ and $\xi)$ (Tashian, 2000; Hewett-Emmett, 1996).

Antibiotics are widely used to treat many different disease and so many investigations reported their effects on enzyme activities. Some of these drugs were either increases or decreases in mammalian enzyme activities, and the activator or inhibitor effects of some antibiotics have been investigated. A lot of researches are reported, different type of drugs and chemicals have inhibition effects on CAs. (Britta, 1997; Cankaya, 2012; Chiche, 2009; Supuran, 2004).

Clindamycin is an antimicrobial agent used in the world for more than thirty years and clindamycin used as an effective treatment to infections of formed by many facultative and obligatory anaerobic bacteria (Brook, 2005).

Dexketoprofen is a non-steroidal drug which is water-soluble salt of an enantiomer of ketoprofen, used treatment to pain reliever, anti-inflammatory and antipyretic since 1973 (Veys, 1991). Dexketoprofen can inhibit prostaglandin synthesis in vitro conditions even at low doses (Barbanoj, 2001).

Benzylpenicillin (penicillin G) which is one of the natural penicillin group members is acid-labile and better absorbed by injection, in that reasons it is used in the form of parenteral and intramuscular injection. Phenoxymethylpenicillin (penicillin V), which is the oral administration of single natural penicillin. Activity against Gram-positive bacteria, penicillin G is similar. (Holten, 2000; Neu, 1982; Prince, 1983).

The effects of many of the known xenobiotics have not been checked on sheep liver CA isozymes yet. Usage of these drugs may worsen SCA 1 and II activity in liver. So, they may be used in sheep necrotic hepatitis disease; it is important to explore the effect of these on CA I and II activity during necrotic hepatitis disease. The present study was realized on the in vitro effect of clindamycin, dexketoprofen trometamol, benzylpenicillin (penicillin G) and phenoxymethylpenicillin (penicillin V) on SCA I and II isozymes purified from sheep liver by Sepharose-4B-L tyrosine-sulfanilamide affinity gel chromatography.

EÜFBED - Fen Bilimleri Enstitüsü Dergisi Cilt-Sayı: 8-2 Yıl:2015 201-212 
Effect of Some Drugs on Sheep Liver Carbonik Anhydrase I and II

\section{MATERIALS AND METHODS}

\section{Chemicals}

Sepharose 4B, protein assay reagents and 4-nitrophenylacetate were obtained from Sigma-Aldrich Co. (Sigma-Aldrich Chemie $\mathrm{GmbH}$ Export Department Eschenstrasse 5, 82024 Taufkirchen, Germany). All other chemicals were analytical grade and obtained from Merck (Merck KGaA Frankfurter strasse 250, D 64293 Darmstadt Germany).

Purification of carbonic anhydrase isozymes from sheep liver by affinity chromatography

The purification of the two SCA isozymes from sheep liver was performed in a simple single-step method by means of Sepharose-4B-L tyrosine-sulfanilamide affinity gel chromatography. Sheep liver was obtained from Erzincan Municipal Slaughterhouse and stored at $-80{ }^{\circ} \mathrm{C}$ until usage. Fifty grams of thawed liver was used in this investigation. All of the experiments were made according to Çoban and friends (Ayvaz, 2013; Çoban, 2007; Çoban, 2008).

\section{Hydratase activity assay}

CA activity was assayed by following the hydration of $\mathrm{CO}_{2}$ according to the method described by Öztürk Sarıkaya, Gülçin and Supuran (2010). $\mathrm{CO}_{2}$-hydratase activity as an enzyme unit (EU) was calculated by using the equation $\left(t_{o}-t_{c} / t_{c}\right)$ where $t_{o}$ and $t_{c}$ are the times for $\mathrm{pH}$ change of the non-enzymatic and the enzymatic reactions, respectively (Öztürk, 2010).

\section{Esterase activity assay}

CA activity was assayed according to method of Verpoorte et al. (Verpoorte, 1967) described previously by Innocenti et al. (Innocenti, 2010a,b). CA activity was determined by following the change in absorbance at $348 \mathrm{~nm}$ of 4-nitrophenylacetate (NPA) to 4nitrophenylate ion over a period of $3 \mathrm{~min}$ at $25^{\circ} \mathrm{C}$ using a spectrophotometer (Perkin Elmer Lambda 35) according to the method described by Verpoorte et al. (Verpoorte, 1967). The inhibitory effects of clindamycin, dexketoprofen trometamol, Benzylpenicillin (penicillin G), Phenoxymethylpenicillin (penicillin V) were examined. All compounds were tested in triplicate at each concentration used. Different inhibitor concentrations were used. SCA I enzyme activities were measured for Phenoxymethylpenicillin

EÜFBED - Fen Bilimleri Enstitüsü Dergisi Cilt-Sayı: 8-2 Yıl: 2015 201-212 
Çankaya ve Kuzucu

(0.123-0.247 mM), Benzylpenicillin (0.21-0.35 mM), clindamycin (11.76-23.52 $\mathrm{mM})$ and dexketoprofen trometamol $(4.8-8 \mathrm{mM})$ at cuvette concentrations and SCA II enzyme activities were measured for Phenoxymethylpenicillin $(0,185-0,309 \mathrm{mM})$, Benzylpenicillin $(0.21$ $0.35 \mathrm{mM})$, clindamycin (17.64-29.4 $\mathrm{mM})$ and dexketoprofen trometamol (0.042-0.053 mM) at cuvette concentrations. Control cuvette activity in the absence of inhibitor was taken as $100 \%$. For each inhibitor an Activity (\%)-[Inhibitor] graphs were drawn. To determine $\mathrm{Ki}$ values, three different inhibitor concentrations were tested. In these experiments, 4-nitrophenylacetate was used as substrate at five different concentrations $(0.15-0.75 \mathrm{mM})$. The Lineweaver-Burk curves were drawn (Lineweaver, 1934).

\section{Protein determination}

Protein during the purification steps was determined spectrophotometrically at $595 \mathrm{~nm}$ according to the Bradford method (Bradford, 1979), using bovine serum albumin as the standard (Hisar, 2005).

\section{SDS polyacrylamide gel electrophoresis}

SDS polyacrylamide gel electrophoresis was performed after purification of the sheep liver isozymes. It was carried out according to Laemmli procedure (Laemmli, 1970). The electrophoretic pattern was photographed (Figure 1).

\section{RESULTS AND DISCUSSION}

In this study, CA I and II were purified from sheep liver by a simple one step procedure using Sephrarose 6B-aniline-sulfanilamide affinity column. The activity of the effluents was determined by the hydratase method, with $\mathrm{CO}_{2}$ as substrate and further kinetic studies were performed using the esterase activity method, with 4nitrophenyl acetate (NPA) as substrate. SCA I was purified 120.62 fold with specific activity (1108.51 EU mg/ $\mu \mathrm{L}$ ) and yield (64\%) (Table $1)$.

Similarly, SCA II was purified 620.96 fold with specific activity (5706.67 EU mg/ $\mu \mathrm{L}$ ) and yield (53\%). SDS-PAGE of the enzymes showed a single polypeptide band (Figure. 1).

EÜFBED - Fen Bilimleri Enstitüsü Dergisi Cilt-Sayı: 8-2 Yıl: 2015 201-212 
Effect of Some Drugs on Sheep Liver Carbonik Anhydrase I and II

Table 1. Purification steps of CA I and II from sheep liver by Sepharose-4B-L tyrosine sulfanilamide affinity gel chromatography.

\begin{tabular}{|c|c|c|c|c|c|c|c|c|}
\hline & $\begin{array}{l}\text { Acti } \\
\text { vity } \\
\text { (EU/ } \\
\text { mL) }\end{array}$ & $\begin{array}{c}\text { Tot } \\
\text { al } \\
\text { Vol } \\
\text { ume } \\
(\mathrm{mL} \\
\text { ) }\end{array}$ & $\begin{array}{c}\text { Prot } \\
\text { ein } \\
(\mathrm{mg} / \\
\mathrm{mL})\end{array}$ & $\begin{array}{c}\text { Tota } \\
1 \\
\text { Prot } \\
\text { ein } \\
(\mathrm{mg})\end{array}$ & $\begin{array}{c}\text { Tota } \\
1 \\
\text { Acti } \\
\text { vity } \\
\text { (EU) }\end{array}$ & $\begin{array}{l}\text { Spec } \\
\text { ific } \\
\text { Acti } \\
\text { vity } \\
\text { (EU/ } \\
\text { mg) }\end{array}$ & $\begin{array}{l}\text { Reco } \\
\text { very } \\
(\%)\end{array}$ & $\begin{array}{c}\text { Purific } \\
\text { ation } \\
\text { (Fold) }\end{array}$ \\
\hline $\begin{array}{l}\text { Homo } \\
\text { genate }\end{array}$ & 155 & 42 & 16.86 & $\begin{array}{c}708 . \\
12\end{array}$ & 6510 & 9.19 & 100 & 1.0 \\
\hline CA-I & 521 & 8 & 0.47 & 3.76 & 4168 & $\begin{array}{c}1108 . \\
51\end{array}$ & 64 & 120.62 \\
\hline CA-II & 856 & 4 & 0.15 & 0.6 & 3424 & $\begin{array}{c}5706 . \\
67\end{array}$ & 53 & 620.96 \\
\hline
\end{tabular}

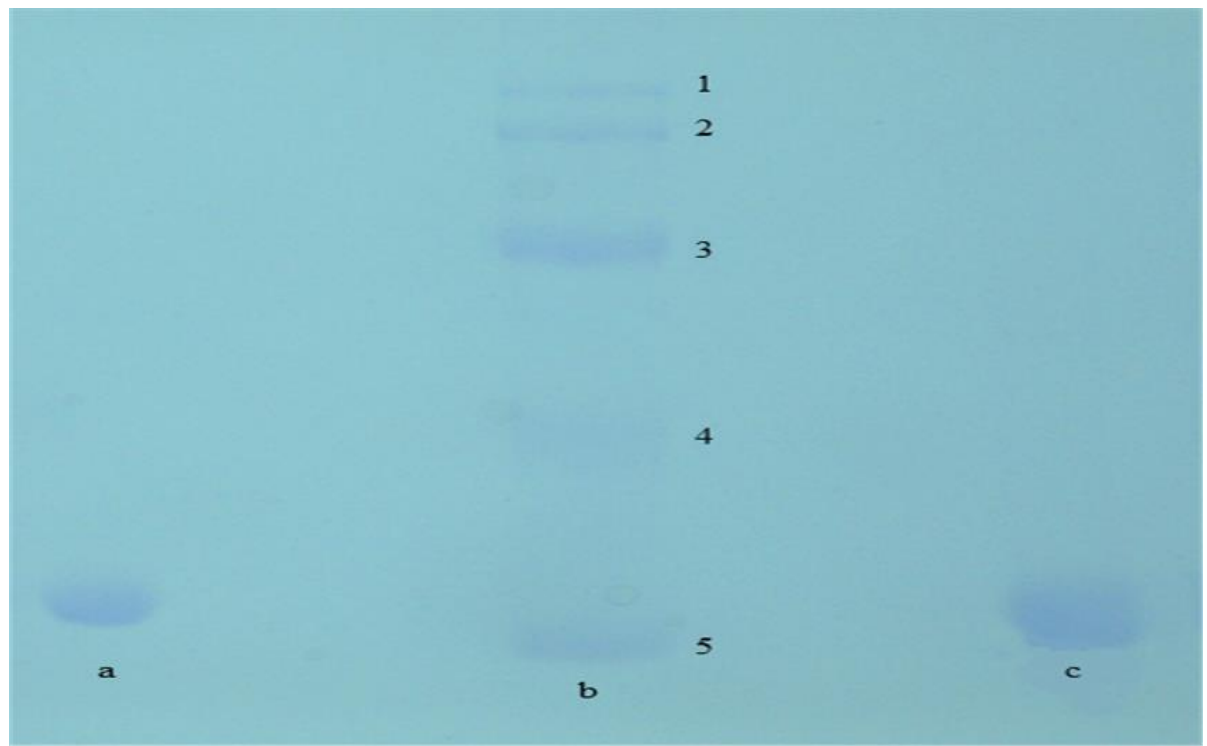

Figure 1. PAGE of the purified CA isozymes. Lane b: Standards: 1. E.coli $\beta$-galactosidasem $(116 \mathrm{kDa}), 2$ 2. Rabbit muscle phosphorylase-b (97 kDa), 3. Bovine serum albumine (66 $\mathrm{kDa}) ; 4$. ovalbumine $(45 \mathrm{kDa}), 5$. bovine erythrocyte CA (29 $\mathrm{kDa})$,, lane a: SCA I, lane c: SCA II.

Four inhibitors were prepared and evaluated for the inhibitory effects on SCA I and II. The inhibitory effects of drugs were 
Çankaya ve Kuzucu

tested in range of $0.001-1000 \mathrm{mM}$. Among the four inhibitor all of them (clindamycin, dexketoprofen trometamol, benzylpenicillin and phenoxymethylpenicillin) were showed inhibition effects on SCA I and SCA II (Table 2). The results obtained from esterase and CO2hydratase methods support each other.

Table 2. IC values of four drugs for the esterase and hydratase activities of sheep erythrocytes CA-I and II

\begin{tabular}{|c|c|c|c|c|c|c|c|c|}
\hline \multirow{2}{*}{$\begin{array}{c}\text { Compou } \\
\text { nd } \\
\text { Name }\end{array}$} & \multicolumn{2}{|c|}{$\begin{array}{l}\text { Hydratase } \\
\text { activity of }\end{array}$} & \multirow{2}{*}{$\begin{array}{c}\mathbf{K}_{\mathbf{i}} \\
\text { SCA } \\
\mathbf{I} \\
(\mu \mathrm{M})\end{array}$} & \multirow{2}{*}{$\begin{array}{l}\text { Inhibi } \\
\text { tion } \\
\text { type }\end{array}$} & \multicolumn{2}{|c|}{$\begin{array}{c}\text { Esterase activity } \\
\text { of }\end{array}$} & \multirow{2}{*}{$\begin{array}{c}\mathbf{K}_{\mathbf{i}} \\
\mathrm{SC} \\
\mathrm{A} \text { II } \\
(\mu \mathrm{M} \\
)\end{array}$} & \multirow{2}{*}{$\begin{array}{c}\text { Inhibit } \\
\text { ion } \\
\text { type }\end{array}$} \\
\hline & $\begin{array}{c}\mathrm{IC}_{50} \\
\text { SCA-I } \\
(\mu \mathrm{M})\end{array}$ & $\begin{array}{c}\mathrm{IC}_{50} \\
\text { SCA- } \\
\text { II } \\
(\mu \mathrm{M})\end{array}$ & & & $\begin{array}{c}\mathrm{IC}_{50} \\
\text { SCA-I } \\
(\mu \mathrm{M})\end{array}$ & $\begin{array}{c}\mathrm{IC}_{50} \\
\text { SCA-II } \\
(\mu \mathrm{M})\end{array}$ & & \\
\hline $\begin{array}{l}\text { Phenoxy } \\
\text { methylp } \\
\text { enicillin }\end{array}$ & 0,462 & $\begin{array}{c}0,582 \\
6\end{array}$ & $\begin{array}{c}0.068 \\
6\end{array}$ & $\begin{array}{l}\text { Non- } \\
\text { compe } \\
\text { titive }\end{array}$ & 0.155 & 0.1938 & $\begin{array}{c}0.08 \\
33\end{array}$ & $\begin{array}{l}\text { Non- } \\
\text { compet } \\
\text { itive }\end{array}$ \\
\hline $\begin{array}{l}\text { Benzylp } \\
\text { enicillin }\end{array}$ & 0,869 & 0,731 & 0.1 & $\begin{array}{l}\text { Non- } \\
\text { compe } \\
\text { titive }\end{array}$ & 0.283 & 0.235 & $\begin{array}{c}0.13 \\
46\end{array}$ & $\begin{array}{c}\text { Non- } \\
\text { compet } \\
\text { itive }\end{array}$ \\
\hline $\begin{array}{c}\text { Clindam } \\
\text { ycin }\end{array}$ & 47,23 & 69,58 & 9.157 & $\begin{array}{c}\text { Non- } \\
\text { compe } \\
\text { titive }\end{array}$ & 15.76 & 22.74 & $\begin{array}{c}9.75 \\
2\end{array}$ & $\begin{array}{l}\text { Non- } \\
\text { compet } \\
\text { itive }\end{array}$ \\
\hline $\begin{array}{c}\text { Dexketo } \\
\text { profen } \\
\text { trometa } \\
\text { mol }\end{array}$ & 13,02 & 9,17 & 2.203 & $\begin{array}{l}\text { Non- } \\
\text { compe } \\
\text { titive }\end{array}$ & 4.26 & 2.909 & $\begin{array}{c}2.71 \\
7\end{array}$ & $\begin{array}{c}\text { Non- } \\
\text { compet } \\
\text { itive }\end{array}$ \\
\hline
\end{tabular}

The liver's highly specialized tissues regulate a wide variety of high-volume biochemical reactions, including the synthesis and breakdown of small and complex molecules, many of which are necessary for normal vital functions. All enzymes involved in detoxification of xenobiotics in the liver tissue, the working $\mathrm{pH}$ should be stable. Carbonic anhydrase has important role in stabilizing the $\mathrm{pH}$. Many antibiotic and antihistamine may have dangerous effect to sheep liver and its detoxification enzymes. In the current study, we examined the effects of some drugs on liver CA I and II enzymes activity of sheep. And as we know, sheep liver is an important source of nutrient for people. The aim of this study is purifying SCAI and II from unstudied tissue of sheep liver and examining the effects of clindamycin, dexketoprofen trometamol,

EÜFBED - Fen Bilimleri Enstitüsü Dergisi Cilt-Sayı: 8-2 Yıl: 2015 201-212 
Benzylpenicillin, Phenoxymethylpenicillin on enzyme activity (Ciftci, 2000; Esbaugh, 2006; Senturk, 2008).

So far, CA consists of 16 isozymes which have been identified in mammals and several novel isozymes have also been identified in non-mammalian vertebrates. Much of the research on the evolution of the structure and function of CA has been focused on the widely distributed CA I and II isozymes (Senturk, 2008). The purification of the two CA isozymes used here was performed with a simple step method by a Sepharose-6B-aniline- sulfanilamide affinity column (Table 1). Inhibition effects of drugs derivatives on enzyme activities were tested under in vitro conditions; $\mathrm{IC}_{50}$ values were calculated Activity (\%)- [Inhibitor] graphs and are given in Table 2 and $K_{i}$ values were calculated from Lineweaver-Burk graphs and are given in Table 2.

CA catalyzes the conversion of $\mathrm{CO}_{2}$ to $\mathrm{H}_{2} \mathrm{CO}_{3}$ at cells and intracellular fluid. Inhibitor of carbonic anhydrase are very important for different diseases such as antiglaucoma, diuretics, antiepileptics, in the management of mountain sickness, gastric and duodenal ulcers, neurological disorders or osteoporosis (Supuran, 2000).

CA I and II have been purified many times from different organisms and the effects of various chemicals, pesticides and drugs on its activity have been investigated (Beydemir, 2000; Demir, 2004; Ottlecz, 1999; Ekinci, 2007).

As a result of our study, sheep liver CA-I and II isozymes were purified in one-step with high specific activity by the purification method used in this study. Inhibitory effects of clindamycin, dexketoprofen trometamol, benzylpenicillin and phenoxymethylpenicillin were demonstrated. Benzylpenicillin and phenoxymethylpenicillin at low concentrations showed in vitro inhibitory effects on SCA-I and SCA-II activity. Dexketoprofen trometamol showed less in vitro inhibitory effects on SCA-I and SCAII activity than benzylpenicillin and phenoxymethylpenicillin. Clindamycin showed lowest in vitro inhibitory effects on SCA-I and SCA-II activity.

$\mathrm{pH}$ is an important chemical parameters in enzymatic activity. For this reason, the enzymes responsible for the detoxification of the liver, is in a relationship with carbonic anhydrases. If carbonic

EÜFBED - Fen Bilimleri Enstitüsü Dergisi Cilt-Sayı: 8-2 Yıl: 2015 201-212 
Çankaya ve Kuzucu

anhydrase activity be inhibit, the activity of detoxification enzymes are not able to fully. For this reasons, uncontrolled usage of these drugs can cause serious side effects and can be deleterious to health. In conclusion, these drugs must be used carefully and the dosage should be closely monitored to decrease side effects.

\section{REFERENCES}

Ayvaz, S., Cankaya, M., Atasever, A. Altuntas, A. 2013. 2-Amino-3cyanopyridine derivatives as carbonic anhydrase inhibitors, Journal of Enzyme Inhibition and Medicinal Chemistry, 28, 305310.

Barbanoj, M.J., Antonijoan, R.M., Gich, I. 2001. Clinical pharmacokinetics of Dexketoprofen, Clinical Pharmacokinetics, 40, 245-262.

Beydemir, S., Ciftçi, M., Ozmen, I., Buyukokuroglu, M.E., Ozdemir, H., Küfrevioglu, O.I. 2000. Effects of some medical drugs on enzyme activities of carbonic anhydrase from human erythrocytes in vitro and from rat erythrocytes in vivo, Pharmacological Research, 42, 187-191.

Bradford, M. 1979. A rapid and sensitive method for the quantitation of microgram quantities of protein utilizing the principle of protein-dye binding, Analytical Biochemistry, 72, 248-254.

Brinkman, R., Margaria, R., Meldrum, N.U., Roughton, F.J.W. 1932. The $\mathrm{CO}_{2}$ catalyst present in blood, The Journal of Physiology, 75, 3-4.

Britta, K., Ralf, R. 1997. $\beta$-lactam antibiotics inhibit chloroplast division in a moss (Physcomitrella patens) but not in tomato (Lycopersicon esculentum), Journal of Plant Physiology, 150, 137140.

Brook, I., Lewis, M.A.O., Sandor, G.K.B., Jeffcoat, M., Samaranayake, L.P., Rojas, J.V. 2005. Clindamycin in dentistry: More than just effective prophylaxis for endocarditis?, Oral Surg. Oral Med. Oral Pathol. Oral Radiol. Endod., 100, 550-558.

Cankaya, M., Aktas, M., Kuzucu, M., Gül, I., Coban, T.A. 2012. Effects of some drugs on human cord blood erythrocyte carbonic anhydrases I and II: an in vitro study, Journal of Enzyme Inhibition and Medicinal Chemistry, 27, 641-645.

EÜFBED - Fen Bilimleri Enstitüsü Dergisi Cilt-Sayı: 8-2 Yıl: 2015 201-212 
Effect of Some Drugs on Sheep Liver Carbonik Anhydrase I and II

Chegwidden, W.R., Carter, N.D. 2000. Introduction to the carbonic anhydrases, EXS, 90, 13-28.

Chiche, J.I., Laferrière, K., Trottier, J., Dayan, E., Mazure, F., Brahimi, Horn, N.M., Pouysségur, M.C. 2009. Hypoxia-inducible carbonic anhydrase IX and XII promote tumor cell growth by counteracting acidosis through the regulation of the intracellular $\mathrm{pH}$, Cancer Research, 69, 358-368.

Ciftci, M., Kufrevioglu, O.I., Gundogdu, M., Ozmen, I. 2000. Effects of some antibiotics on enzyme activity of glucose 6-phosphate dehydrogenase from the human erythrocytes, Pharmacol Research, 41, 109-113.

Çoban, T.A., Beydemir, Ş., Gülçin, İ., Ekinci, D. 2007. Morphine inhibits erythrocyte carbonic anhydrase in vitro and in vivo, Biological and Pharmaceutical Bulletin, 30, 2257-2261.

Çoban, T.A., Beydemir, Ş., Gülçin, İ., Ekinci, D. 2008. The inhibitory effect of ethanol on carbonic anhydrase isozymes: in vivo and in vitro studies, Journal of Enzyme Inhibition and Medicinal Chemistry, 23, 266-270.

Demir, Y., Nadaroğlu, H., Demir, N. 2004. Effects of omeprazole, famotidine, and ranitidine on the enzyme activities of carbonic anhydrase from bovine stomach in vitro and rat erythrocytes in vivo, Biological and Pharmaceutical Bulletin, 27, 1730-1734.

Demirdag, R., Yerlikaya, E. and Kufrevioglu, O.I. 2012. Purification of carbonic anhydrase-II from sheep liver and inhibitory effects of some heavy metals on enzyme activity, Journal of Enzyme Inhibition and Medicinal Chemistry, 27, 795-9.

Ekinci, D., Beydemir, S., Alim, Z. 2007. Some drugs inhibit in vitro hydratase and esterase activities of human carbonic anhydrase-I and II, Pharmacological Reports, 59, 580-587.

Esbaugh, A.J., Tufts, B.L. 2006. The structure and function of carbonic anhydrase isozymes in the respiratory system of vertebrates, Respiratory Physiology and Neurobiology, 154, 185-198.

Evenepoel, P., Laleman, W., Wilmer, A., Claes, K., Kuypers, D., Bammens, B., Nevens, F., Vanrenterghem, Y. 2006. Prometheus Versus Molecular Adsorbents Recirculating System: Comparison Of Efficiency In Two Different Liver Detoxification Devices, Artificial Organs, 30, 276-284.

EÜFBED - Fen Bilimleri Enstitüsü Dergisi Cilt-Sayı: 8-2 Yıl: 2015 201-212 
Çankaya ve Kuzucu

Hewett-Emmett, D., Tashian, R.E. 1996. Functional diversity, conservation, and convergence in the evolution of the $\alpha_{-}^{-}, B_{-}$, and $\mathrm{Y}$-carbonic anhydrase gene families, Molecular Phylogenetics and Evolution, 5, 50-77.

Hisar, O., Beydemir, Ş., Gülçin, İ., Küfrevioğlu, Ö.İ., Supuran, C.T. 2005. Effect of low molecular weight plasma inhibitors of rainbow trout (Oncorhyncytes mykiss) on human erythrocytes carbonic anhydrase-II isozyme activity in vitro and rat erythrocytes in vivo, Journal of Enzyme Inhibition and Medicinal Chemistry, 20, 35-39.

Holten, K.B., Onusko, E.M. 2000. Appropriate prescribing of oral beta-lactam antibiotics, American Family Physician, 62, 611-620.

Innocenti, A., Gülçin, İ., Scozzafava, A., Supuran, C.T. 2010a. Carbonic anhydrase inhibitors. Antioxidant polyphenol natural products effectively inhibit mammalian isoforms I-XV, Bioorganic and Medicinal Chemistry Letters, 20, 5050-5053.

Innocenti, A., Öztürk, Sarıkaya, S.B., Gülçin, İ., Supuran, C.T. $2010 b$. Carbonic anhydrase inhibitors, Inhibition of mammalian isoforms I-XIV with a series of natural product polyphenols and phenolic acids, Bioorganic and Medicinal Chemistry, 18, 2159-2164.

Kmieć, Z. 2001. Cooperation of liver cells in health and disease. Advances in Anatomy, Embryology and Cell Biology, 161, 1-151.

Laemmli, U.K. 1970. Cleavage of structural proteins during the assembly of the head of bacteriophage T4, Nature, 227, 680-685.

Lineweaver, H., Burk, D.J. 1934. The determination of enzyme dissociation constants, Journal of the American Chemical Society, 57, 666-685.

Meldrum, N.U., Roughton, F.J.W. 1933. Carbonic anhydrase; Its preparation and properties, The Journal of Physiology, 80, 113142.

Neu, H.C. 1982. Antistaphylococcal penicillins, Medical Clinics of North America, 66, 51-60.

Ottlecz, A., Romero, J.J., Lichtenberger, L.M. 1999. Effect of ranitidine bismuth citrate on the phospholipase A2 activity of Naja naja venom and Helicobacter pylori: a biochemical analysis, Alimentary Pharmacology and Therapeutics, 13, 875-888.

EÜFBED - Fen Bilimleri Enstitüsü Dergisi Cilt-Sayı: 8-2 Yıl: 2015 201-212 
Effect of Some Drugs on Sheep Liver Carbonik Anhydrase I and II

Öztürk, Sarıkaya, S.B., Gülçin, I.,, Supuran, C.T. 2010. Carbonic anhydrase inhibitors, Inhibition of human erythrocyte isozymes I and II with a series of phenolic acids, Chemical Biology and Drug Design, 75, 515-520.

Prince, A.S., Neu, H.C. 1983. New penicillins and their use in pediatrics, Pediatric Clinics of North America, 30, 33-39.

Senturk, M., Gulcin, I., Ciftci, M. and Kufrevioglu, O.I. 2008. Dantrolene inhibits human erythrocyte glutathione reductase, Biological and Pharmaceutical Bulletin, 31, 2036-2039.

Stadie, W.C., O'Brien, H. 1933. The catalysis of the hydration of carbon dioxide and dehydration of carbonic acid by an enzyme isolated from red blood cells, The Journal of Biological Chemistry, 103, 521-529.

Supuran, C.T., Scozzafava, A., Conway, J. 2004. Carbonic anhydraseits inhibitors and activators, CRC Press.

Supuran, C.T., Scozzafava, A. 2000. Carbonic anhydrase inhibitors and their therapeutic potential, Expert Opinion on Therapeutic Patents, 10, 575-600.

Tashian, R.E., Hewett-Emmett, D., Carter, N., Bergenhem, N.C.H. 2000. Carbonic anhydrase (CA)-related proteins (CA-RPs), and transmembrane proteins with $\mathrm{CA}$ or CA-RP domains, In: Chegwidden WR, Carter N, Edwards YH (Eds.), The Carbonic Anhydrases, New Horizons, 105-120.

Verpoorte, J.A., Mehta, S., Edsall, J.T.J. 1967. Esterase activities of human carbonic anhydrases B and C, The Journal of Biological Chemistry, 242, 4221-4229.

Veys, E.M. 1991. 20 years experience of ketoprofen, Scandinavian Journal of Rheumatology, 90, 1-44.

EÜFBED - Fen Bilimleri Enstitüsü Dergisi Cilt-Sayı: 8-2 Yıl: 2015 201-212 